\title{
PERSEPSI ANAK SEKOLAH DASAR TERHADAP KOMUNIKASI VERBAL BERUPA KRITIKAN DARI ORANG TUA DI KOTA BANDUNG
}

\author{
Lucia Voni Pebriani ${ }^{1}$, Ditha Prasanti ${ }^{2}$, dan Puspita Adhi Kusuma W. ${ }^{3}$ \\ ${ }^{1,3}$ Fakultas Psikologi Universitas Padjadjaran \\ ${ }^{2}$ Fakultas Ilmu Komunikasi Universitas Padjadjaran \\ Jl. Raya Bandung-Sumedang KM.21 Jatinangor, Sumedang, Jawa Barat \\ Email: lucia.voni@unpad.ac.id
}

Diserahkan 13 April 2019; Diterima 21 Juli 2019; Dipublikasikan 01 Agustus 2019

\begin{abstract}
ABSTRAK
Proses komunikasi orang tua kepada anaknya berpengaruh terhadap pembentukan karakter anak. Anak usia sekolah dasar (usia 8-12 tahun) sudah memahami komunikasi verbal yang dilakukan orang tua kepada dirinya. Pada dasarnya, bentuk komunikasi verbal yang dilakukan orang tua kepada anaknya bisa bermacam-macam. Penelitian ini fokus pada persepsi anak usia sekolah dasar mengenai komunikasi verbal berbentuk kritikan yang dilakukan orang tua. Penelitian kuantitatif ini memiliki responden penelitian yang usia usia 8-12 tahun di Bandung sejumlah 403 orang (laki-laki $=41,9 \%$, perempuan $=58,15 \%$ ), yang didapat dengan metode cluster random sampling. Alat ukur yang digunakan adalah Perceived Criticism Inventory (PCI) versi Bahasa Indonesia dengan reliabilitas 0,98. Hasil penelitian ini menunjukkan (Quantity of Perceived Criticism/PCI-Q) sebanyak 44\% anak usia 8-12 tahun di kota Bandung mempersepsi bahwa kadang-kadang orang tua mereka memberikan kritikan, $40 \%$ orang tua mereka sering memberikan kritikan dan hanya $8 \%$ dari orang tua mereka yang jarang memberikan kritikan terhadap mereka. Isi kritikan (Content of Perceived Criticism/PCI-C) yang paling banyak adalah mengenai komitmen anak yang rendah dalam mengerjakan tanggung jawab tertentu, serta bentuk kritikan (Form of Perceived Criticism/PCI-F) yang paling banyak dilakukan tanpa disertai kekerasan.
\end{abstract}

Kata kunci: persepsi; anak; sekolah dasar; komunikasi verbal; kritikan; orang tua; Bandung

\section{ELEMENTARY SCHOOL CHILDREN PERCEPTION TO VERBAL COMMUNICATION OF THE PARENTAL CRITICISM IN BANDUNG CITY}

\begin{abstract}
The process of communication of parents to their children affects the formation of children's character. Primary school age children (ages 8 12 years) already understand their parents' verbal communication to themselves.Forms of verbal communication by parents to their children are varied. This study focuses on the perception of elementary school-age children regarding verbal communication in the form of criticism made by parents. This quantitative research respondents were 403 children aged 8-12 years in Bandung (male $=41.9 \%$, female $=58.15 \%)$, obtained by cluster random sampling method. The measuring instrument used was the Indonesian version of the Perceived Criticism Inventory (PCI) with reliability of 0.98. The results indicate that (Quantity of Perceived Criticism / PCI-Q) as many as $44 \%$ of children aged 8-12 years in Bandung perceived that their parents give criticism only sometimes, $40 \%$ of their parents give criticism quite often and only $8 \%$ from their parents who criticize them rarely. The most critical content (Content of Perceived Criticism / PCI-C) was about the low commitment of children in carrying out certain responsibilities. The form of Perceived Criticism / PCI-F which is most often carried out without any violence.
\end{abstract}

Keywords: perception; elementary school; children; verbal communication; criticism; parents; Bandung

\section{PENDAHULUAN}

Komunikasi menjadi bagian yang penting dalam interaksi antar individu, baik dalam lingkup keluarga, teman, kelompok masyarakat, dan kehidupan sosial lainnya. Dalam lingkup keluarga, proses komunikasi orang tua kepada anaknya berpengaruh terhadap pembentukan karakter anak. Anak usia akhir dalam penelitian ini, merupakan anak yang memiliki usia 8-12 tahun, di mana anak tersebut sudah memahami komunikasi verbal yang dilakukan orang tua kepada dirinya. Dari sisi perkembangan berpikir, usia anak akhir berfikir lebih logis daripada sebelumnya karena pada saat ini mereka dapat mengambil berbagai aspek dari 
situasi tersebut ke dalam pertimbangan. Walaupun demikian, mereka masih dibatasi untuk berpikir tentang situasi yang sebenarnya pada saat itu saja. Pada masa kanak-kanak pertengahan, penilaian tentang diri menjadi lebih realistis, berimbang, komprehensif, dan lebih terekspresikan secara sadar (Harter,1998). Sekitar usia 7 atau 8 tahun, seorang anak memiliki kemampuan kognitif untuk membentuk sistem representasional: konsep diri inklusif dan luas yang mengintegrasikan berbagai aspek diri.

Merujuk pada Erikson (1982, dalam Harter, 1998), faktor penentu harga diri adalah pandangan anak akan kemampuan kerja produktif mereka. Isu yang harus dipecahkan pada masa kanak-kanak pertengahan ialah industry versus inferiority. "Kebijakan" yang berkembang bersama dengan resolusi krisis ini adalah kompetensi, yaitu pandangan yang memandang diri sendiri mampu menguasai keterampilan dan menuntaskan tugas.

Dari sisi perkembangan emosi, anak menjadi lebih peka terhadap perasaan-perasaannya sendiri dan orang lain. Mereka dapat lebih baik mengatur ekspresi emosi mereka dalam situasi sosial, dan mereka dapat merespons tekanan emosional orang lain (Saarni et al, 1998). Pada usia 7 atau 8 tahun, rasa malu dan rasa bangga yang tergantung kepada kesadaran mereka akan implikasi tindakan mereka dan jenis sosialisasi yang pernah anak terima, mempengaruhi pandangan mereka terhadap diri mereka sendiri (Harter, 1998). Anak dapat menyadari bahwa mereka memiliki dua perasaan yang sejenis terhadap target yang berbeda. Akan tetapi, mereka tidak dapat menerima untuk memiliki dua perasaan yang berlawanan. Pada usia 8-10 tahun, anak sudah dapat mengintegrasikan rangkaian emosi positif dan negatif. Mereka dapat memahami memiliki dua perasaan yang saling bertolak belakang dalam satu waktu, tetapi hanya jika diarahkan kepada target yang berbeda. Misalnya, Ashley dapat mengekspresikan perasaan negatif terhadap adik bayinya (saya marah kepada Tony jadi saya mencubitnya) dan perasaan positif kepada ayahnya (saya senang ayah tidak memukul saya), tetapi dia tidak dapat menyadari bahwa ia memiliki perasaan positif dan negatif (marah dan sayang) kepada mereka berdua.

Jika mendasar kepada perkembangan aspek kognitif dan sosial yang terjadi pada anak usia akhir, komunikasi yang terjadi antara orang tua dan anak akan mempengaruhi dirinya, baik itu mempengaruhi pemahaman ia mengenai dirinya atau kemampuannya, yang dapat berujung pada perasaan inferior atau industri (perasaan diri mampu) seperti halnya yang disampaikan oleh Erikson.

Mengingat pentingnya komunikasi terhadap perasaan dan harga diri anak kelak, perlunya kita memahami bagaimana pola komunikasi orang tua anak, khususnya pola komunikasi yang sehat. Pola komunikasi yang sehat sangat bergantung kepada fungsi dari komunikasi itu sendiri yaitu (i) penamaan atau penjulukan merujuk pada usaha mengidentifikasikan objek, tindakan, atau orang dengan menyebut namanya sehingga dapat dirujuk dalam komunikasi; (ii) fungsi interaksi menekankan berbagi gagasan dan emosi, yang dapat mengundang simpati dan pengertian atau kemarahan dan kebingungan, (iii) fungsi transmisi, yaitu menyampaikan pada orang lain melalui Bahasa. Keistimewaan bahasa sebagai fungsi transmisi informasi yang lintas-waktu, dengan menghubungkan masa lalu, masa kini, dan masa depan, memungkinkan kesinambungan budaya dan tradisi kita (Mulyana, 2010: 81).

Apabila setiap fungsi komunikasi tersebut bertema negatif yaitu jika penamaan atau penjulukan ditujukan secara negatif kepada anak, atau jika fungsi interaksi yang dilakukan mengundang kemarahan atau kebingungan, serta fungsi transimisi dari transmisi informasi yang diberikan lebih banyak mengenai masa lalu yang negatif atau masa depan yang pesimis, hal tersebut akan mempengaruhi perilaku anak secara negatif pula.

Fungsi tersebut bisa jadi dipengaruhi adanya keterbatasan bahasa yaitu keterbatasan jumlah kata yang tersedia untuk mewakili objek, kata-kata bersifat ambigu dan kontekstual, kata-kata mengandung bias budaya atau adanya percampuradukkan fakta, penafsiran, dan penilaian. Dalam berbahasa kita sering mencampuradukkan fakta (uraian), penafsiran (dugaan), dan penilaian. Masalah ini berkaitan dengan dengan kekeliruan persepsi (Mulyana, 2010). Ketika berkomunikasi, kita menerjemahkan gagasan kita ke dalam bentuk lambang (verbal atau nonverbal). Proses ini lazim disebut penyandian (encoding). Bahasa adalah alat penyandian, tetapi alat yang tidak begitu baik (lihat keterbatasan bahasa di atas), untuk itu diperlukan kecermatan dalam berbicara, bagaimana mencocokkan kata dengan keadaan sebenarnya, bagaimana menghilangkan kebiasaan berbahasa yang menyebabkan kerancuan dan kesalahpahaman.

Makna dapat pula digolongkan ke dalam makna denotatif dan konotatif. Makna denotatif adalah makna yang sebenarnya (faktual), seperti yang kita temukan dalam kamus dan diterima secara umum oleh kebanyakan orang dengan bahasa dan kebudayaan yang sama. Makna konotatif adalah makna yang subyektif, mengandung penilaian tertentu atau emosional. Salah satu komunikasi yang dilakukan oleh orang tua kepada anak adalah saat memberi evaluasi terhadap suatu hal yang sudah anak kerjakan, yang bisa jadi secara negatif berbentuk kritik. Kritik orang tuamerupakan ucapan verbal atau hukuman pada anak oleh orang tua yang didasarkan pada performa yang buruk, menerapkan standar yang tinggi dan tidak memahami atau menerima kesalahan anak. Seperti halnya pujian dari orang tua 
yang memberikan makna khusus pada anak, kritikan dari orangtua juga bisa sangat menyakitkan hati anak. Pickhardt (2013) mengatakan bahwa terdapat 3 macam kritikan, yaitu:

a. Constructive Criticism. Kritikan ini adalah keseimbangan kebaikan, dan ini diberikan dengan cara membantu. Jenis kritikan ini sangat edukatif dan diberikan sesuai permintaan. Misalnya ketika remaja menginginkan ibunya yang dapat menulis dengan baik, remaja tersebut meminta ibunya untuk melihat hasil tulisannya dan membuat saran sebelum ia mengumpulkan tugasnya. Dalam situasi lain, ketika seorang atlet muda menginginkan ayahnya yang juga seorang atlet untuk memberikan ia umpan baik terkait kekuatan dan kelemahan dari performanya dalam sebuah pertunjukan. Contoh lainnya, bisa juga ketika seorang remaja meminta saran pada orangtuanya mengenai pekerjaan atau hubungannya dengan lawan jenis. Pemberian kritikan berpusat pada kesejahteraan remaja tersebut yang menjadikan kritik tersebut dapat diterima dengan baik.

b. Corrective Criticism. Kritikan ini juga seimbang karena apapun yang dikatakan orang tua tidak baik dan kebutuhan untuk berubah selalu diberikan dalam konteks yang positif. Sebagai tambahan, karena koreksi ditujukan pada kesalahan atau perilaku yang menyimpang yang orangtua sering ubah, dan hal ini cukup kritikal, maka tidak diperlukan tambahan complain atau kecaman. Tetaplah pada kritikan korektif yang tidak mengevaluasi, dan berfokus pada pilihan perilaku remaja, tidak pada kegagalan dari karakternya. Sebuah pernyataan kritikan yang korektif akan terdengar seperti, "Aku tidak setuju dengan dengan pilihan yang kamu buat, dan itulah kenapa saya harus memberimu konsekuensi”.

c. Corrosive Criticism. Kritik yang korosif biasanya diberikan dalam keadaan marah, maka potongan pertama dari saran tidak pernah mengkritik dalam kemarahan. Begitu juga ketika orang tua merasa tersakiti atau bersalah, mereka beresiko untuk memberikan rasa sakit pada anaknya juga. Misalnya

\section{METODE}

Penelitian ini merupakan penelitian kuantitatif dengan pemilihan responden menggunakan metoda cluster random sampling. Karakteristik responden dalam penelitian ini merupakan anak 8-12 tahun di Bandung, dengan jumlah responden sebanyak 403 orang (laki-laki= $41,9 \%$, perempuan $=58,15 \%)$. Pengambilan data diawali dengan meminta izin kepada Kepala Sekolah untuk masing-masing sekolah serta menjelaskan mekanisme pengambilan data.

$$
\text { Data responden didapat dengan }
$$

"kamu tidak pernah belajar! Kamu tidak pernah melakukan sesuatu dengan benar! Kenapa kamu tidak berpikir untuk berubah? Sarkasme dapat menjadi kritikan yang korosif dan paling merusak. Ketika orang dewasa meminta maaf untuk kata-kata yang telah diucapkan, hal ini tidak dapat mengembalikan rasa sakit yang mereka alami. Lebih buruknya, kritikan yang korosif adalah racun dalam self-rejection dari seorang remaja, sehingga parental criticism sebenarnya menjadi sebuah kepercayaan terhadap inferiority mereka. Jika dikaji dari konteks komunikasi verbal, hal ini sungguh menarik, karena dalam prinsip komunikasi dikatakan bahwa komunikasi bersifat irreversible, artinya pesan yang telah disampaikan tidak dapat ditarik kembali. Orang tua yang korosif dapat menurunkan harga diri remaja. Dengan demikian, remaja yang direndahkan oleh orang tua mereka karena dianggap telah mengecewakan orang tua mereka, seorang remaja dapat menjadi merasa bersalah. Hal ini menjadikan mereka merasa tidak berguna.

Koestner, Zuroff \& Powers (1991) mendemostrasikan bahwa pengalaman akan parental criticism pada 5 tahun pertama kehidupan seseorang akan memprediksi adanya self-criticism di usia 12 tahun dan self-critism tersebut akan tetap bertahan pada usia dewasa. Penelitan tambahan pada Koestner et al juga membuktikan adanya bukti yang prediktif antara parental criticism dengan self-criticism (Brewin, Andrews, Furnham, 1996: Sachs-Ericsson, 2006).

Di Indonesia, penelitian-penelitian terkait komunikasi anak dan orang tua baru sekedar pola komunikasi antara orangtua dan anak ataupun pola asuh orangtua kepada anak. Namun belum terdapat penelitian yang spesifik terkait dengan kritik yang dilakukan oleh orang tua kepada anak. Berdasarkan fenomena tersebut maka peneliti tertarik untuk meneliti gambaran persepsi anak usia akhir terhadap komunikasi verbal berbentuk kritikan dari orang tua (parental criticism) yang terjadi di kota Bandung. Anak usia akhir yang dimaksud dalam penelitian ini adalah anak dalam rentang usia 8-12 tahun

\section{menggunakan kuesioner Perceived Criticism Inventory (PCI) versi Bahasa Indonesia} (Apparigliato, Ruggiero, \& Sassaroli, 2007). Kuesioner ini digunakan untuk mengukur persepsi anak terhadap kritik yang ditujukan kepada dirinya, khususnya dalam hal ini adalah kritik dari orang tua. Kuesioner ini terdiri dari 4 bagian yaitu:

1. PCI-Q (Quantity of Perceived Criticism) adalah bagian kuesioner yang membahas mengenai jumlah kritikan. Bagian PCI-Q ini terdiri dari 11 item.

2. PCI-C (Content of Perceived Criticism) adalah bagian kuesioner yang berisi konten atau isi dari kritikan, Jumlah item 20 buah, yang terbagi menjadi 3 jenis item yaitu (1) Item yang 
merepresentasikan teguran atau kritikan pada ketidakmampuan personal, (2) Item yang merepresentasikan kritik karena komitmen yang rendah, (3) Item yang merepresentasikan kritik karena kebencian.

3. PCI-F (Form of Perceived Criticism) adalah bagian ketiga dari kuesioner yang menggali terkait bentuk kritikan. Bagian ini terdiri dari 17 item yang terdiri dari 3 bagian yaitu: (1) Kritikan yang berbentuk kekerasan psikologis. (2) Kritikan yang disertai kekerasan fisik (3)Kritikan tanpa kekerasan (misal: memberitahu kesalahan)

4. PCI-A/DG (Agreement/Disagreement of Perceived Criticism) adalah bagian keempat dari kuesioner yang menggali terkait kesepatakan atau ketidaksepakatan terhadap kritikan. Bagian ini terdiri dari 12 item.

Setiap item harus dijawab dengan memilih salah satu dari 5 pilihan jawaban yaitu Selalu, Sering, Kadang -Kadang, Jarang dan Tidak Pernah, dimana pilihan jawaban tersebut memiliki skor 5 (selalu), 4 (sering, 3 ( kadang-kadang), 2 (jarang) dan 1 (tidak pernah). Skoring secara kuantitatif dilakukan dengan menjumlahkan angka total dari keempat bagian, adapun kategori yang telah dibuat adalah sebagai berikut, Rendah (skor 60-140), sedang (skor 141220) dan kategori tinggi (skor 221-300). Uji reliabilitas telah dilakukan dengan menggunakan SPSS versi 17. Adapun setelah diolah dengan menggunakan Cronbach's Alpha, reliabilitas dari adaptasi instrumen Perceived Criticism Inventory versi bahasa Indonesia adalah 0,98 (reliabilitas tinggi).

\section{HASIL DAN PEMBAHASAN}

\section{Tabel 1 Persentase kategori PCI-Q (Quantity of Perceived Criticism)}

\begin{tabular}{cccccc}
\hline & Selalu & Sering & $\begin{array}{c}\text { KATEGORI } \\
\text { Kadang- } \\
\text { Kadang }\end{array}$ & Jarang & $\begin{array}{c}\text { Tidak } \\
\text { Pernah }\end{array}$ \\
\hline PCI-Q & $7 \%$ & $40 \%$ & $44 \%$ & $8 \%$ & $1 \%$ \\
\hline
\end{tabular}

Tabel 3 Persentase kategori PCI-F (Form of Perceived Criticism)

\begin{tabular}{|c|c|c|c|c|c|c|c|c|c|}
\hline & \multicolumn{9}{|c|}{ KATEG0RI } \\
\hline & \multicolumn{3}{|c|}{ Tanpa kekerasan } & \multicolumn{3}{|c|}{ Kekerasan Fisik } & \multicolumn{3}{|c|}{ Kekerasan Psikologis } \\
\hline & Rendah & Sedang & tinggi & Rendah & Sedang & tinggi & Rendah & Sedang & tinggi \\
\hline PCI-F & $53 \%$ & $40 \%$ & $7 \%$ & $73 \%$ & $22 \%$ & $5 \%$ & $63 \%$ & $32 \%$ & $5,5 \%$ \\
\hline
\end{tabular}

(Sumber: Hasil Penelitian, 2017)

Bentuk kritikan yang paling banyak dilakukan orang tua ditunjukkan pada tabel 3 , dengan data yang
Berdasarkan hasil pengolahan data bagian pertama dari PCI yaitu PCI-Q (Quantity of Perceived Criticism) bagian kuesioner yang membahas mengenai jumlah kritikan pada tabel 1, sebanyak 44\% anak usia 9-10 tahun di Indonesia mempersepsi bahwa kadang-kadang orang tua mereka memberikan kritikan, $40 \%$ orang tua mereka sering memberikan kritikan dan hanya $8 \%$ dari orang tua mereka yang jarang memberikan kritikan terhadap mereka. Sebanyak 7\% dari mereka juga menyatakan bahwa orangtua mereka selalu memberikan kritikan, dan hanya $1 \%$ anak Indonesia yang mempersepsikan bahwa orang tua mereka tidak pernah memberi kritik terhadap mereka.

\section{Tabel 2 Persentase kategori PCI-C (Content of} Perceived Criticism)

\begin{tabular}{|c|c|c|c|c|c|c|c|c|c|}
\hline \multirow[b]{3}{*}{ PCI-C } & \multicolumn{9}{|c|}{ KATEG0RI } \\
\hline & \multicolumn{3}{|c|}{ TidakPunya Kemampuan } & \multicolumn{3}{|c|}{ Kebencian } & \multicolumn{3}{|c|}{ Komitmen rendah } \\
\hline & Rendah & Sedang & tinggi & Rendah & Sedang & tinggi & Rendah & Sedang & tinggi \\
\hline & $93 \%$ & $0 \%$ & $7 \%$ & $67 \%$ & $29 \%$ & $4 \%$ & $54 \%$ & $40 \%$ & $6 \%$ \\
\hline
\end{tabular}

Adapun jika dilihat dari 3 jenis konten kritikan yang paling banyak dipersepsi oleh anak pada tabel 2 adalah berkaitan dengan komitmen yang rendah untuk melaksanakan tanggung jawab (40\%) dan ujaran kebencian (29\%). Secara mendetail, konten kritikan yang termasuk ke dalam jenis komitmen yang rendah misalnya adalah "tidak belajar dengan keras", "menyia-nyiakan keterampilan yang dimilikinya", " seharusnya memperoleh hasil lebih jika mau", "tidak bekerja keras sebanyak yang dapat dilakukan". Konten kritikan yang termasuk ke dalam ujaran kebencian misalnya "saya anak nakal", "tidak bertanggung jawab", "seperti anak yang tidak pernah diajari oleh orang tua", " tidak menghormati orang lain", "tidak tahu bagaimana berperilaku dengan baik", serta "tidak memiliki rasa hormat"

mengarah lebih banyak tidak mengandung unsur kekerasan fisik maupun kekerasan psikologis, namun masih terdapat anak yang mempersepsikan bahwa orang tua mereka memberikan kritik dengan bentuk kekerasan psikologis misalnya: mempermalukan, tidak mempertimbangkan pendapat anak, membandingkan anak dengan orang lain, meninggikan volume suara, menghina, menunjukan ketidaksetujuan. Sementara itu, masih terdapat juga orang tua yang memberikan kritik dalam bentuk kekerasan fisik, misalnya: menendang 
anak, menunjuk-nunjuk anak, memukul dan menggunakan cara-cara kekerasan yang lainnya.

Isi dan bentuk dari kritikan yang paling sering khas muncul dilakukan oleh orang tua di Indonesia adalah berkaitan dengan kegagalan yang dilakukan oleh anak. Kkegagalan yang terjadi pada anak yang dianggap karena anak tidak memiliki kemampuan untuk melakukan hal yang gagal tersebut. Misalnya: anak dianggap ceroboh, berbuat salah, tidak cukup mampu, tidak memikirkan akibat dari tindakan yang dilakukan, tidak melakukan yang terbaik, tidak memiliki kemampuan dalam hal apapun, seharusnya melakukan hal dengan lebih baik, tidak mencapai hal yang diharapkan oleh orang tua, sering menimbulkan kekacauan atau masalah. Ini juga terkait dengan salah satu cara orangtua indonesia dalam menerapkan disiplin pada anak adalah dengan membuat anak merasa malu di depan orang lain.

Selain itu menurut Fitriana (2015) Orang tua menganggap bahwa anak adalah seorang yang tidak tahu apa-apa. Dengan demikian pola asuh apapun berhak dilakukan oleh orangtua. Orangtua yang mempunyai harapan-harapan yang tidak realistik terhadap perilaku anak berperan memperbesar tindakan kekerasan verbal pada anak. Serta kurangnya pengetahuan orang tua tentang pendidikan anak dan minimnya pengetahuan agama orangtua dapat melatarbelakangi kejadian kekerasan verbal pada anak (Fitriana, 2015).

\section{Model Komunikasi Wilbur Schramm}

Salah satu model komunikasi yang menggambarkan adanya proses komunikasi verbal berbentuk kritikan dari orang tua terhadap anaknya adalah model komunikasi Wilbur Schramm. Wilbur Schramm (1954, dalam Mulyana, 2010) memiliki konsep decoding dan encoding sebagai aktivitas yang dilakukan secara simultan oleh pengirim dan penerima, Wilbur juga membuat ketentuan-ketentuan untuk pertukaran dua arah pesan. Schramm memberikan gagasan tambahan "field of experience", atau kerangka acuan psikologis, hal ini merujuk pada jenis orientasi atau sikap dari interactants (orang yang berinteraksi) mempertahankan terhadap satu sama lain.
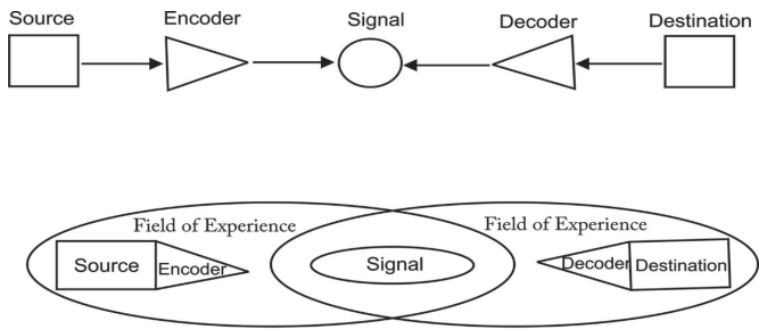

Gambar 1. Model Komunikasi Wilbur Schramm
Model komunikasi ini merupakan model yang relevan menggambarkan tentang persepsi anak usia akhir di kota Bandung terhadap komunikasi verbal berbentuk kritikan dari orang tuanya. Dalam hal ini, orang tua sebagai komunikator (source) memberikan pesan verbal berupa kritikan kepada anaknya (destination). Ada faktor utama yang mempengaruhi proses komunikasi keduanya yaitu field of experience (kerangka pengalaman) yang dimiliki oleh orang tua dan anak tentu saja jauh berbeda. Dalam model Wilbur Shcramm ini digambarkan bahwa orang tua juga berperan sebagai encoder dan anaknya berperan sebagai decoder. Jadi, ada proses penyandian pesan dan penyandian balik yang dilakukan keduanya.

Ketika orang tua menyampaikan pesan verbal yang berbentuk kritikan, maka terjadilah proses penyandian pesan tersebut dari pihak anaknya. Hal ini relevan dengan konten dari parental criticism sendiri bahwa kritikan yang korosif adalah racun dalam selfrejection dari seorang remaja, sehingga parental criticism sebenarnya menjadi sebuah kepercayaan terhadap inferiority mereka. Jika dikaji dari konteks komunikasi verbal, hal ini sungguh menarik, karena dalam prinsip komunikasi dikatakan bahwa komunikasi bersifat irreversible, artinya pesan yang telah disampaikan tidak dapat ditarik kembali. Orang tua yang korosif dapat menurunkan harga diri anak. Dengan demikian, anak yang direndahkan oleh orang tua mereka karena dianggap telah mengecewakan orang tua mereka, seorang anak dapat menjadi merasa bersalah. Hal ini menjadikan mereka merasa tidak berguna.

Beberapa penelitian menegaskan bahwa definisi kritik orang tua lebih merujuk pada ciri corrosive criticism. Seperti yang dikatakan SachsEricsson, Verona Joiner\& Preacher (2006) bahwa menghina, mengutuk mengancam dengan ancaman fisik, atau dikatakan bahwa ia tidak berharga dan berguna adalah contoh-contoh dari kritik orang tua. Kritik orang tua dapat secara negatif berdampak pada seorang anak, dan dihubungkan secara spesifik pada self-criticism (Koestner, Zuroff \& Powers, 1991). Self-critism adalah sebuah bentuk yang membahayakan dari evaluasi diri yang melibatkan perasaan tidak berguna dan rasa bersalah, sebuah rasa kegagalan, dan merasa ditolak atau dikritik oleh orang lain terhadap performanya pada kehidupan sehari-hari (Cox, Fleet, \& Stein, 2004).

\section{SIMPULAN}

Penelitian ini dilakukan pada anak usia sekolah dasar di kota Bandung. Data siswa didapat dengan menggunakan kuesioner Perceived Criticism Inventory (PCI). Hasil penelitian yang telah dilakukan menunjukkan adanya sebanyak 44\% anak usia 9-10 tahun di Bandung mempersepsi bahwa kadang-kadang orang tua mereka 
memberikan kritikan, $40 \%$ orang tua mereka sering memberikan kritikan dan hanya $8 \%$ dari orang tua mereka yang jarang memberikan kritikan terhadap mereka. Sebanyak 7\% dari mereka juga menyatakan bahwa orangtua mereka selalu memberikan kritikan, dan hanya $1 \%$ anak usia sekolah dasar di Bandung yang mempersepsikan bahwa orang tua mereka tidak pernah memberi kritik terhadap mereka. Isi kritikan (Content of Perceived Criticism/PCI-C) yang paling banyak adalah mengenai komitmen anak yang rendah dalam mengerjakan tanggung jawab tertentu, serta bentuk kritikan (Form of Perceived Criticism/PCI-F) yang paling banyak dilakukan tanpa disertai kekerasan.

\section{DAFTAR PUSTAKA}

Apparigliato, M., Ruggiero, G. M., \& Sassaroli, S. (2007). Il Perceived Criticism Inventory (PCI): un nuovo strumento di valutazione del criticismo genitoriale [The Perceived Criticism Inventory (PCI): a new instrument for evaluating parental criticism]. Psicoterapia Cognitiva Comportamentale (pp.275300)

Brewin C R, Andrews B, \& Furnham A (1996). Selfcritical attitudes and Parental criticism in young women. British Journal of Medical Psychology (pp.69-78)

Cox BJ, Fleet C, \& Stein MB (2004). Self-criticism and social phobia in the US national comorbidity survey. Journal of Affective Disorders (pp.227-234).

Dunsmore, Julie., Halberstadt, Amy., Robinson, Megan. (2004). Mother's Negative

Evaluations of their children's performance enhance boys's memories for crafts. The Journal of Genetic Psychology (pp.345-365)

Fitriana, Y., Pratiwi, K., \& Sutanto, A. V. (2015). Faktor-faktor yang berhubungan dengan perilaku orang tua dalam melakukan kekerasan verbal terhadap anak usia pra-sekolah. Jurnal Psikologi, 14(1), 81-93.

Hagan, Christopher R. (2014). Associations Between Perceived Criticism and Suicide Ideation and Attempts. Florida State University Libraries

Harter, S., Waters, P., \& Whitesell, N. R. (1998). Relational self-worth: Adolescents perceptions of their worth as a person in different relational contexts. Child Development, 69, 756-766.

Harris, D.Irving. (1984). Parental Criticism and the Adolescent Experience. Journal of Youth and Adolescence, Vol. 13, No. 2

Koestner R, Zuroff DC, \& Powers TA (1991). Family origins of adolescent selfcriticism and its continuity into adulthood. Journal of Abnormal Psychology (pp.191-197)

Miller, Thomas W. (2007) Praise or criticism with children. Journal of Family Counselling (pp. 55-57)

Mulyana, Deddy. (2010). Pengantar Ilmu Komunikasi. PT Remaja Rosdakarya: Bandung.

Pickhardt, C. (2013). Surviving your child's adolescence: How to understand, and even enjoy, the rocky road to independence. John Wiley \& Sons.

Sachs-Ericsson N, Verona E, Joiner T, \& Preacher KJ (2006). Parental verbal abuse and the mediating role of self-criticism in adult internalizing disorders. Journal of Affective Disorders (pp. 71-78)

Whitesell, N. R., Robinson, N. S., \& Harter, S. (1993). Coping with anger-provoking situations: Young adolescents' theories of strategy use and effectiveness, Journal of Applied Developmental Psychology, 14, 521-545. 